\title{
The Role of Visuo-spatial Sketchpad in the Written Production of Descriptive and Argumentative Texts.
}

\section{J-M. Passerault and J. Dinet}

\author{
(2) OpenEdition \\ Journals \\ Electronic version \\ URL: http://journals.openedition.org/cpl/130 \\ DOI: $10.4000 / \mathrm{cpl} .130$ \\ ISSN: $1379-6100$ \\ Publisher \\ Centre PsyCLÉ
}

\section{Printed version}

Date of publication: 1 December 2000

\section{Electronic reference}

J-M. Passerault and J. Dinet, « The Role of Visuo-spatial Sketchpad in the Written Production of Descriptive and Argumentative Texts. », Current psychology letters [Online], 2000/3, 3 | 2000, Online since 04 September 2003, connection on 08 September 2020. URL : http://journals.openedition.org/ cpl/130; DOI : https://doi.org/10.4000/cpl.130

This text was automatically generated on 8 September 2020 .

(c) All rights reserved 


\section{The Role of Visuo-spatial Sketchpad in the Written Production of Descriptive and Argumentative Texts.}

J-M. Passerault and J. Dinet 